\title{
Quality of agricultural extension on productivity of farmers: Human capital perspective
}

\author{
Hasmin Tamsan $^{\mathrm{a}^{*}}$ and Yusriadi Yusriadi ${ }^{\mathrm{b}}$
}

${ }^{a}$ Sekolah Tinggi Ilmu Ekonomi AMKOP, Indonesia

${ }^{b}$ Sekolah Tinggi Ilmu Administrasi Puangrimaggalatung, Indonesia

\section{A B S T R A C T}

\begin{tabular}{l}
\hline Article history: \\
Received July 25, 2021 \\
Received in revised format \\
September 24, 2021 \\
Accepted October 292021 \\
Available online \\
November 152021 \\
\hline Keywords: \\
Agricultural extension quality \\
Soft-skill competence \\
Farmers productivity
\end{tabular}

\section{Introduction}

Indonesia's agricultural sector still plays an essential role in economic growth, job creation, and reducing food insecurity. Agriculture in Indonesia increased to 88881.60 IDR Billion in the second quarter of 2021 from 79203.70 IDR Billion in the first quarter of 2021 (Economics, 2021). Most Indonesian farmers (70\%) are small-scale $(<5 \mathrm{ha})$ and focus on food commodities such as rice, corn, vegetables, and livestock production (Statistik, 2020). In Indonesia, smallholders face several obstacles in increasing productivity and implementing sustainable agriculture principles. They practice traditional types of agriculture with intensive use of inputs (Altieri \& Nicholls, 2017). However, increasing agricultural productivity and preserving the environment has become the most pressing issues facing the international development community in recent years (Robertson \& Swinton, 2005; Voicu \& Radulescu, 2015). In this context, various policies and approaches are applied in most countries, including Indonesia, to increase the adoption of innovations by farmers and to promote sustainable agricultural growth (Adnan et al., 2017; Lee et al., 2006; Mariyono, 2019). Globally, agricultural extension services were developed as an institutional contribution to modernize agriculture and encourage rural development (Eze et al., 2010; Knickel et al., 2009; Ragasa et al., 2016; Rivera, 2011). Agricultural extension services are defined as the entire network of organizations that help individuals involved in agricultural operations solve problems and gain information, skills, and technology to better their livelihoods and well-being (Devi \& Tripathi, 2020). Agricultural extension workers are responsible for increasing farmers' knowledge to change their behavior to improve the welfare of farmers and their families (Baloch \& * Corresponding author

E-mail address: hasmintamsah40@gmail.com (H. Tamsan)

(C) 2022 Growing Science Ltd. All rights reserved.

doi: $10.5267 /$ j.uscm.2021.11.003 
Thapa, 2018; Belay \& Abebaw, 2004). Agricultural extension is non-formal education aimed at farmers and their families with the short-term goal of changing behavior, actions, attitudes, and knowledge for the better and long-term so that farmers can live prosperously (Comoé \& Siegrist, 2015; McCown, 2002).

The state of Indonesia is one of the national food barns and a provider of other agricultural products such as horticulture and plantations. Therefore, strengthening the agricultural sector through a program to increase production needs to be carried out as soon as possible so that the achievement of self-sufficiency can be realized immediately (Mamai et al., 2019) Previous studies linked the weakness of public extension services to several challenges such as financial constraints, unresponsiveness to farmer needs, common farmer knowledge, inadequate delivery of relevant information (Feder et al., 2001, 2011; Leta et al., 2017; Meena et al., 2015). However, evidence from the international literature on the privatization of agricultural extension and consulting systems reveals some risks. These include the risks associated with the exclusion of farmers due to their inability to pay; limited involvement of consulting services in complex innovations; discontinuation of service provision due to the funding model for extension; narrow specialization by consulting services; technology transfer; and reluctance to share purchased knowledge among farmers (Anderson \& Feder, 2004, 2007; Swanson, 2006). The effectiveness of the extension system in achieving the sustainable development plan depends on the quality of the extension and advisory services provided. Sveiby \& Lloyd (2010) suggest a holistic approach to analyzing extension and consulting services called intangible assets from a systems perspective. This approach has five characteristics: knowledge, ideas, creativity, skills, attitudes, and work productivity. What is meant by "knowledge" is information that is known or realized by someone. "ideas" are extension policies, funding mechanisms, coordination and linkages, levels of decentralization, and levels of privatization. "Creativity" is the traditional means and information communication technology (ICT) used by extension workers in interacting with farmers. "Skills" includes the organizational management procedures performed, training for extension staff, incentives, and methods for assessing individual agency performance, and monitoring and evaluating services. "Attitude" refers to financial and physical assets, as well as human and organizational competencies. Finally, "work productivity" is the level of ability to produce products.

In Indonesia, the Central Administration of Agricultural Extension Services (IP2SI) manages public agricultural extension services at the national level in collaboration with the Ministry of Agriculture. There are extension workers for the directorate of agriculture in 34 governorates at the governorate level. At the district level, subject matter specialists work in the extension department to provide information and support to village extension workers. Extension workers at the village level interact with farmers to accept their problems and help provide information by applying various extension methods (Chowa et al., 2013; Gandhi et al., 2007; Hoang et al., 2006). There are several problems faced by agricultural extension services in Indonesia that affect their efficiency and effectiveness. Including lack of funds and extension staff, lack of technical skills and proper qualifications of extension workers, lack of responsiveness to farmers' needs, focus on supply-based approaches, and inefficient use of ICT (Purnomo \& Lee, 2010; Rahayu et al., 2020; Rusliyadi et al., 2018).

\section{Literature review}

\subsection{Theoretical background and hypothesis development}

Research on agricultural extension quality is still lacking, so that references on it are minimal. In this regard, the researcher tries to provide an approach to determining agricultural extension quality indicators. In this study, the author refers to the short-term goals of agricultural extension workers. If an agricultural extensionist achieves at least the short-term extension goal, the extension can be said to be a qualified agricultural instructor. Therefore, the indicators used to refer to the shortterm goals of extension include the level of knowledge, skills, abilities, attitudes, and motivation of farmers towards farming activities carried out (Agholor et al., 2013). Research on the quality of agricultural extension workers, including that quality extension services from the point of view of extension visits, can increase farmers' knowledge (Aker, 2011). If the farmer's knowledge increases, it can also indirectly increase the soft-skill competence of the farmer (Freeman, 2017). Counseling carried out in mentoring can improve abilities (Hauser et al., 2016). On the other hand, agricultural extension quality can be helpful to regional development, cooperation development, farmer leadership, building thinking systems, and others (Setiawan et al., 2021). Furthermore, agricultural extension workers can encourage agricultural productivity (Widayati, 2019).

\subsection{Quality of Agricultural Extension}

Two elements influence service quality: (1) technical quality, which is evaluated subjectively by consumers, and (2) functional quality, which is related to personal views and attitudes between customers and sellers (Simpson \& Calitz, 2015). If the short-term objectives are achieved, which include the knowledge, skills, abilities, attitudes, and motivations of farmers toward the farming operations carried out are characterized as being of high quality (Ajayi, 2007; Brunori et al., 2011, 2011; Plà et al., 2014). In addition to being helpful, well-managed, and accountable to the farmers, a high-quality agricultural extension service is characterized as one that fulfills the requirements of farmers in various agro ecological settings via frequent interaction between farmers and extension workers (Chen, 2020; Harry, 2012). The importance of agricultural instructors having quality knowledge indicators, planning, process, ability, attitude, and motivation can improve farmers' abilities through the transfer of knowledge they do (Dondero, 2019; Free, 2017). 


\subsection{Supply chain risk resilience}

Farmer productivity is determined primarily by how good the quality of the extension is (Bloemer et al., 1999). Consequently, farmer productivity can be described as a mental or emotional response to the quality of services provided to clients (Bloemer et al., 1999). In the context of agricultural extension, farmer productivity is defined as the fulfillment of farmers' initial expectations for the quality of knowledge provided by extension workers (Muwonge, 2007). When measuring farmer productivity, it is essential to consider the effect of extension services and the extent of farmer soft-skill competency, both of which affect the development of trust between farmers and agricultural extension workers in the future (Hazell, 2005). As a result, farmers who have soft-skill competencies are more likely to engage in extension programs and spread the word about the best services they receive (Chapman \& Tripp, 2003). Farmer productivity evaluation is critical in agricultural extension because it helps allocate resources, evaluate performance, and provide information to policymakers (Berry \& Cromie, 2007).

\subsection{Firm performance}

Aspects that affect farmers' productivity to agricultural extension services must be highlighted to provide a complete picture of the productivity of farmers to agricultural extension services. Several previous studies examined various factors affecting productivity, including socioeconomic attributes (Besser \& Mann, 2015), frequency of extension contacts and participation in extension activities, use of several communication methods, and perceived quality of information (Hernández-Espallardo et al., 2013; Lulfs-Baden et al., 2008; Rota et al., 2021).

Regarding the socio-economic aspect, we explain how the quality parameters of agricultural instructors (knowledge, process, ability, attitude, motivation) can affect the productivity of farmers towards agricultural consulting services, as shown in Fig. 1. According to Charatsari et al. (2011), younger farmers are more productive with the services offered by extension workers than older farmers, which can be attributed to their farming experience. On the other hand, younger farmers are usually perceived as more adaptable and eager to engage in new or creative activities for fear of risk. In contrast, older farmers may be more risk-averse to implementing innovations in their farms (Knight et al., 2003).

The soft skill competence of farmers increases the resources and capacity of individuals to achieve goals. In addition, they are increasing farmers' awareness of alternatives and the rewards provided for the activities carried out (Weber et al., 2009). The better the soft skill competence of farmers, the wiser they receive extension services (Free, 2017). In addition, Ghimire \& Suvedi (2017) found that the higher the soft skill competence of farmers, the greater the likelihood of farmer satisfaction in extension services. Therefore, we propose that the level of soft skill competence positively affects the satisfaction of extension services.

The quality of agricultural extension workers is a determinant of agricultural productivity. Various knowledge methods have a positive and significant relationship with the soft-skill competency of farmers on farmer productivity (Brunori et al., 2011; Harry, 2012). In this case, Elias et al. (2016) argue that the frequency of regular extension helps farmers learn about and discuss innovations that positively affect their productivity due to their introduction through their exposure and their decision to adopt. Therefore, extension workers should choose different methods to maximize efficiency, program effectiveness, and client satisfaction (Elias et al., 2016). In addition, extension workers need to understand the dynamics of attitudes and approaches of participatory extension workers and improve their skills in using ICT, increasing farmer productivity (Deichmann et al., 2016; Poulton et al., 2010). In line with these reasons, we propose that the quality of agricultural extension in extension activities positively affects farmer productivity.

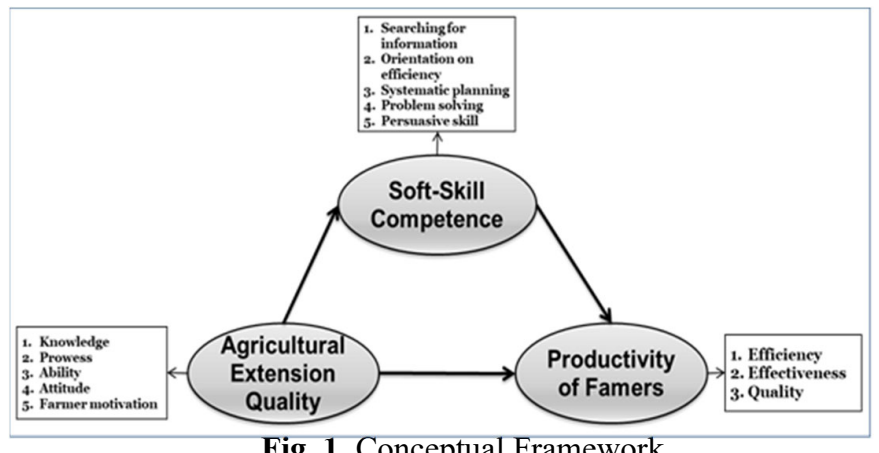

Fig. 1. Conceptual Framework

\section{Research method}

\subsection{Sample and data collection}

It tested this research model with online questionnaire data (google form) to all agricultural extensions in South Sulawesi and West Sulawesi on a convenience and voluntary basis. This is done because of the pandemic, so it cannot do it face-to-face. The population of this study is all agricultural extensions in South Sulawesi and West Sulawesi; the sample is determined through the accidental sampling technique (Etikan et al., 2016). Which is randomly assigned to anyone willing to fill out an 
online questionnaire, with a sampling target of at least 100 people who fill out early, that a quantitative approach will be more accurate with SEM-Amos if it has respondents between 100-200 respondents (Shamsudin, 2020). Each incoming questionnaire is given a respondent number if all statements in the questionnaire are filled out. Until the specified time limit, only 122 agricultural extension people filled out the questionnaire, and it was declared complete.

Collecting data using a survey with a Likert scale $(1=$ strongly disagree, $2=$ disagree, $3=$ neutral, $4=$ agree, $5=$ strongly agree) on the statements in the questionnaire. The sample in this study is as many as 122 agricultural extension workers, as many as 95 people (77.9\%) live in South Sulawesi, and the remaining 27 people (22.1\%) live in West Sulawesi. Male respondents as many as 79 people $(64.8 \%)$ and female as many as 43 people $(35.2 \%)$. The dominant respondents with S1 education are 110 people $(90.2 \%)$, while S2 is six people $(4.9 \%)$, D3 is five people $(4.1 \%)$, and S3 is one person $(0.8 \%)$. Furthermore, the age of the respondents in the range of 20 - 30 years was five people $(4.0 \%)$, the range of 31 - 40 years was 25 people $(20.5 \%)$, the range of $41-50$ years was 64 people $(52.5 \%)$, and the range of 51-60 years as many as 28 people $(30.0 \%)$. They were chosen as respondents for two reasons. First, they are all agricultural extension officers who work in the two provinces that are the targets of this research. Second, they fill out voluntarily and entirely to be used as respondents in this study.

\subsection{Measurement}

It researched three variables (dependent and independent), namely agricultural extension quality, soft-skill competence, and farmers' productivity. Agricultural extension quality is measured by indicators of knowledge, prowess, ability, attitude, and farmer motivation (Lukuyu et al., 2012). Soft-Skill Competence is measured by indicators searching for information, orientation on efficiency, systematic planning, problem-solving, and persuasive skills (Mislia et al., 2021; Riyanti et al., 2017). The productivity of Farmers is measured by indicators of efficiency, effectiveness, and quality (Berry \& Cromie, 2007; Chapman \& Tripp, 2003).

Table 1

The Measurement of variable

\begin{tabular}{|c|c|c|}
\hline Variable & Indicators & $\begin{array}{ll} & \text { Item } \\
\end{array}$ \\
\hline \multirow{5}{*}{$\begin{array}{l}\text { Agricultural } \\
\text { extension } \\
\text { quality } \\
\text { (AEQ) }\end{array}$} & Knowledge (AEQ1) & $\begin{array}{l}\text { know what information is needed by farmers. } \\
\text { aware that the quality of knowledge is essential in mapping problems }\end{array}$ \\
\hline & Prowess (AEQ2) & $\begin{array}{l}\text { competent extension agents following the needs in the field } \\
\text { In delivering material to farmers, qualified skills are needed }\end{array}$ \\
\hline & Ability (AEQ3) & $\begin{array}{l}\text { able to deliver extension materials by the agricultural development program. } \\
\text { Extension officers must have the ability to read the situation in the field }\end{array}$ \\
\hline & Attitude (AEQ4) & $\begin{array}{l}\text { trying to change the attitude of the farmers according to the rules and conditions in the field. } \\
\text { changes in farmer attitudes depend on the ability of extension workers }\end{array}$ \\
\hline & $\begin{array}{l}\text { Farmer motivation } \\
\text { (AEQ5) }\end{array}$ & $\begin{array}{l}\text { encourage the search for solutions in solving farmer problems. } \\
\text { able to increase farmer motivation }\end{array}$ \\
\hline \multirow{5}{*}{$\begin{array}{l}\text { Soft-Skill } \\
\text { Competence } \\
\text { (SSC) }\end{array}$} & $\begin{array}{l}\text { Searching for } \\
\text { information (SSC1) }\end{array}$ & $\begin{array}{l}\text { the ability to share the latest information. } \\
\text { the ability to find relevant information }\end{array}$ \\
\hline & $\begin{array}{l}\text { Orientation on efficiency } \\
\text { (SSC2) }\end{array}$ & $\begin{array}{l}\text { get farming methods to work efficiently } \\
\text { practice good farming methods }\end{array}$ \\
\hline & $\begin{array}{l}\text { Systematic planning } \\
\text { (SSC3) }\end{array}$ & $\begin{array}{l}\text { able to do systematic planning. } \\
\text { able to make regular steps in work }\end{array}$ \\
\hline & Problem-solving (SSC4) & $\begin{array}{l}\text { responsive and alert to the problems at hand } \\
\text { able to find a solution faced }\end{array}$ \\
\hline & Persuasive skill (SSC5) & $\begin{array}{l}\text { able to communicate ideas } \\
\text { convincing to change }\end{array}$ \\
\hline \multirow{3}{*}{$\begin{array}{l}\text { Productivity } \\
\text { of Farmers } \\
(\text { PoF })\end{array}$} & Efficiency (PoF1) & $\begin{array}{l}\text { improvement of working relations among farmers } \\
\text { improvement of working relations between farmers and stakeholders } \\
\text { there is a guarantee for health care for farmers. } \\
\text { the existence of social security for farmers' employment }\end{array}$ \\
\hline & Effectiveness (PoF2) & $\begin{array}{l}\text { improvement of work ethics for farmers } \\
\text { improvement of farmer work discipline }\end{array}$ \\
\hline & Quality (PoF3) & $\begin{array}{l}\text { improvement of farmers' skills } \\
\text { improvement of farmer work experience }\end{array}$ \\
\hline
\end{tabular}

\subsection{Data and analysis}

This study uses an explanatory quantitative approach with the analytical tool used is Structural Equation Modeling (SEM) as fundamental data analysis (Shamsudin, 2020; Wan Omar \& Hussin, 2013) and processed the data using AMOS software. It selected the SEM-Amos analysis technique with structural equations in testing models and hypotheses for several things. First, structural equations with modeling that can work with several equations at once are not the same as regression analysis which has to perform calculations several times according to the number of structural equations. Variables can represent predictors (regressors) in one equation and criteria (regressions) in another equation. Here are the regression equations of the concepts we built, although all of them can be calculated using SEM-Amos automatically: 


$$
\begin{aligned}
& S S C=\alpha A E Q+e 1 \\
& P o F=\beta A E Q+\theta S S C+e 2 \\
& P o F=\beta A E Q+\theta(\alpha A E Q+e 1)+e 2 \\
& P o F=\beta A E Q+\alpha \theta A E Q+\theta e 1+e 2 \\
& P o F=(\beta+\alpha \theta) A E Q+\theta e 1+e 2
\end{aligned}
$$

$$
\begin{array}{ll}
\text { Explanation: } \\
\text { SSC } \quad=\text { Soft-skill competence } \\
\text { AEQ } \quad=\text { Agricultural extension quality } \\
\begin{array}{ll}
\text { PoF } & =\text { Productivity of Farmers } \\
\alpha & =\text { regression coefficient of the relationship between AEQ and SSC } \\
\beta & =\text { regression coefficient of the relationship between SSC and PoF } \\
\theta & =\text { regression coefficient of the relationship between AEQ and PoF }
\end{array}
\end{array}
$$

Second, using SEM in analysis has the advantage of testing the mediation process simultaneously (Almeqbali \& Kasim, 2020). We carry out two steps in testing our model with SEM analysis. Before measuring the influence between variables, it collected data through two stages of testing. The first test was carried out using the Confirmatory Factor Analysis (CFA) technique. CFA aims to confirm that each indicator can accurately measure its latent variables (Brown \& Moore, 2012; Harrington, 2009). An indicator is said to measure its latent variable if the indicator has a loading factor coefficient $>0.5$. A good indicator is also indicated by the Critical Ratio (CR) value greater than two and the Standard Error (SE), which does not indicate a poor fit value. SE values that are too small are close to zero and too large indicate that the model has poor fit data (McCloskey \& Ziliak, 1996). CFA also aims to assess the construct validity of the conceptualized measurement theory. The measurement of construct validity in this study uses the Construct Reliability (CR) and Variance Extracted (VE) values. The validity of the data on a construct is indicated by the value of $\mathrm{CR}>0.7$ and VE $>0.5$. Valid data provide confidence that the indicator measure (table 1) is taken from a sample that describes the actual score in the population.

The next testing stage is model fit testing which aims to see whether the data obtained in this study can confirm the conceptualized research model (Cai \& Lee, 2009). The Goodness of Fit value indicates the results of this test from the AMOS output. A data in the model is declared to have conformity if the Goodness fit of Model (GoF) criterion has a small, expected Chi-Square value; RMSEA < 0.08; GFI > 0.90; AGFI > 0.90; Degree of Freedom > 2.0; CFI and TLI >0.95.

Meanwhile, the mediating effect of soft-skill competence is expected to explore the impact of improving agricultural extension quality on farmers' productivity, as stated by the hypothesis. The calculation process refers to the views and procedures of (Baron \& Kenny, 1986). We carried out the process using an online Sobel-test (see Fig. 3).

\section{Results}

The results of statistical testing in Table 2 show that the overall p-value of variables and items is significant $<0.01$. On average, the critical ratio item value is above 7.676, and the standard error value (S.E) compared to the estimated value is also very small. The value of the standardized estimate of the variable item, in general, is above 0.67 , which indicates that the item intervention on the standardized estimate value is in a high range. The test results also showed that it deleted several items because the validity value and the estimated standard were not fulfilled, such as the Soft-Skill Competence (SSC) variable, namely Searching for information (SSC1) and Orientation on Efficiency (SSC2).

Other test results show that the dominant component items in forming the Agricultural Extension Quality (AEQ) variable are Ability $(\mathrm{AEQ} 3)=0.813$. The variable Soft-Skill Competence $(\mathrm{SSC})$ is problem-solving $(\mathrm{SSC} 4)=0.842$. In the Productivity of Farmers $(\mathrm{PoF})$ variable is Efficiency $(\mathrm{PoF} 1)=0.844$. The explanation in Table 2 illustrates that the feasibility test of the model has met the requirements for Structural Equation Modeling. As in the normality test with the Kolmogorov-Smirnov, Asymp method. Sig $=0.20>0.05$ so that the normality assumption has been fulfilled and is feasible for the next test. Then the Goodness of Fit model, described by the values of Chi-Square, DF, GFI, TLI, AGFI, and RMSEA, also shows the achievement of ideal values, and most of the model eligibility tests state that the model in this study is Fit. The results of model testing include $\mathrm{CMIN}=1,510$; GFI $=0.919$; $\mathrm{TLI}=0.963 ; \mathrm{CFI}=0.973$; and $\mathrm{RMSEA}=0.065$ while Chi-square $=$ 61.911; $\mathrm{Sig}=0.019 ; \mathrm{DF}=41$; and $\mathrm{AGFI}=0.870$ also indicates that this model is good enough to describe this research. Likewise, with the indicators of each variable showing estimates $>0.5$; C.R $>1.96$; and $p$-value $<0.05$ so it can interpret that all indicators are valid and suitable to be used to measure each latent construct. The Structural Model is described in Fig. 2. 
Table 2

The Statistical Result

\begin{tabular}{|c|c|c|c|c|c|c|}
\hline Variables & Item & $\begin{array}{l}\text { Standardized } \\
\text { Estimate }\end{array}$ & Estimate & $\begin{array}{l}\text { Standard } \\
\text { Error (S.E) }\end{array}$ & $\begin{array}{l}\text { Critical } \\
\text { Ratio } \\
\text { (C.R) }\end{array}$ & P-Value \\
\hline \multirow{5}{*}{$\begin{array}{l}\text { Agricultural } \\
\text { Extension Quality } \\
\text { (AEQ) }\end{array}$} & Knowledge (AEQ1) & 0,713 & 0,826 & 0,100 & 8,281 & $* * *$ \\
\hline & Prowess (AEQ2) & 0,672 & 0,871 & 0,113 & 7,676 & $* * *$ \\
\hline & Ability (AEQ3) & 0,813 & 1,000 & & & \\
\hline & Attitude (AEQ4) & 0,735 & 0,875 & 0,102 & 8,563 & $* * *$ \\
\hline & Farmer motivation (AEQ5) & 0,769 & 1,017 & 0,115 & 8,858 & *** \\
\hline \multirow{5}{*}{$\begin{array}{l}\text { Soft-Skill } \\
\text { Competence (SSC) }\end{array}$} & Searching for information (SSC1) & deleted item & & & & \\
\hline & Orientation on efficiency (SSC2) & deleted item & & & & \\
\hline & Systematic planning (SSC3) & 0,736 & 0,855 & 0,100 & 8,532 & $* * *$ \\
\hline & Problem solving (SSC4) & 0,842 & 1,134 & 0,113 & 10,040 & $* * *$ \\
\hline & Persuasive skill (SSC5) & 0,805 & 1,000 & & & \\
\hline \multirow{3}{*}{$\begin{array}{l}\text { Productivity of } \\
\text { Farmers (PoF) }\end{array}$} & Efficiency (PoF1) & 0,844 & 1,000 & & & \\
\hline & Effectiveness (PoF2) & 0,828 & 0,520 & 0,049 & 10,591 & $* * *$ \\
\hline & Quality (PoF3) & 0,836 & 0,494 & 0,047 & 10,577 & $* * *$ \\
\hline \multicolumn{2}{|c|}{ Soft-skill Competence $\leftarrow$ Agricultural Extension Quality } & 0,731 & 0,760 & 0,113 & 6,750 & *** \\
\hline \multicolumn{2}{|c|}{ Productivity of Farmers $\leftarrow$ Agricultural Extension Quality } & 0,204 & 0,658 & 0,369 & 1,783 & 0,075 \\
\hline \multicolumn{2}{|c|}{ Productivity of Farmers $\leftarrow$ Soft-skill Competence } & 0,740 & 2,300 & 0,415 & 5,539 & *** \\
\hline \multicolumn{2}{|c|}{$\begin{array}{l}\text { Productivity of Farmers } \leftarrow \text { Soft-skill Competence } \leftarrow \\
\text { Agricultural Extension Quality }\end{array}$} & 0,541 & Sobel-Test & & 4,277 & $* * *$ \\
\hline \multicolumn{2}{|c|}{ Model Fit Testing } & Value & & & Info & \\
\hline \multicolumn{2}{|c|}{ Normality Test (Kolmogorov-Smirnov Test) } & $0.20>0.05$ & & & Normal & rametric \\
\hline \multicolumn{2}{|c|}{ Chi-Square } & 61,911 & & & Ideal & \\
\hline \multicolumn{2}{|l|}{ Degree of Freedom } & 41 & & & Ideal & \\
\hline \multicolumn{2}{|l|}{ CMIN } & 1,510 & & & Fit & \\
\hline \multicolumn{2}{|l|}{ GFI } & $0,92>0.90$ & & & Fit & \\
\hline \multicolumn{2}{|l|}{ AGFI } & $0,87>0.80$ & & & Fit & \\
\hline \multicolumn{2}{|l|}{ TLI } & $0,96>0.90$ & & & Fit & \\
\hline \multicolumn{2}{|l|}{ CFI } & $0,97>0.90$ & & & Fit & \\
\hline \multicolumn{2}{|l|}{ RMSEA } & $0.065<0.08$ & & & Fit & \\
\hline
\end{tabular}

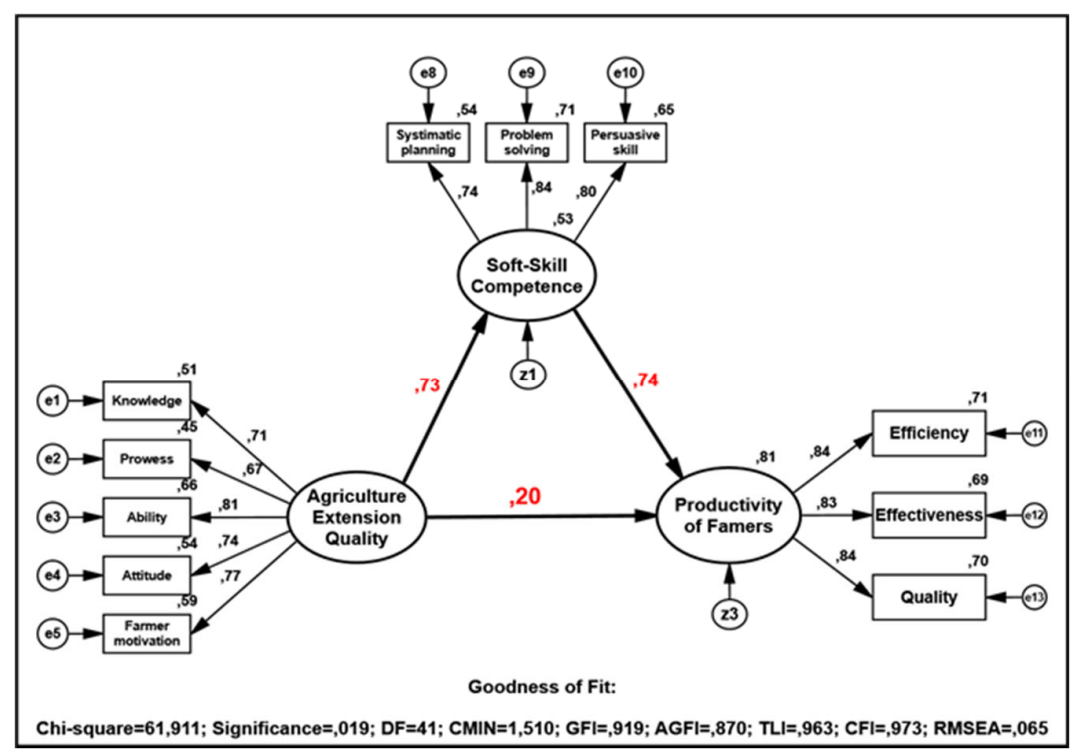

Fig. 2. Structural Equation Model

The results of hypothesis testing through the influence test with the Equation Structural model, which compares the tstatistical value to the p-value value with a significance coefficient of $<0.05$, are the results of hypothesis testing. such as Table 3 shows the relationship between the variables Agricultural Extension Quality (AEQ) on Soft-skill Competence (SSC), Agricultural Extension Quality (AEQ) on Productivity of Farmers (PoF), Soft-skill Competence (SSC) on Productivity of Farmers. (PoF), and Agricultural Extension Quality (AEQ) on Productivity of Farmers (PoF) through Soft-skill Competence (SSC). Overall, Hypotheses H1, H3, and H4 have a positive and significant effect with a significance value $<0.05$, except that $\mathrm{H} 2$ is not substantial. 
Table 3

The Hypothesis Result

\begin{tabular}{|c|c|c|c|c|}
\hline Variable Relationship & Standardized Estimate & C.R & p-value & Remark \\
\hline Agricultural Extension Quality $\rightarrow$ Soft-skill Competence & $\mathbf{0 , 7 3 1}$ & 6,750 & $* * *$ & Supported \\
\hline Agricultural Extension Quality $\rightarrow$ Productivity of Farmers & 0,204 & 1,783 & 0,075 & Not Supported \\
\hline Soft-skill Competence $\rightarrow$ Productivity of Farmers & 0,740 & 5,539 & $* * *$ & Supported \\
\hline $\begin{array}{l}\text { Agricultural Extension Quality } \rightarrow \text { Soft-skill Competence } \rightarrow \text { Productivity of } \\
\text { Farmers }\end{array}$ & 0,541 & 4,277 & $* * *$ & Supported \\
\hline
\end{tabular}

The results of testing the relationship between agricultural extension quality and soft-skill competence show the coefficient value with the loading factor $=0.731 ; \mathrm{C} . \mathrm{R}=6,750$ and $\mathrm{p}$-value $=0,000$; thus, $\mathrm{H} 1$ is accepted. So that agricultural extension quality has a positive and significant effect on soft-skill competence. These results can be stated that the increase in rural extension quality will increase soft-skill competence. The indicators that have the most outstanding contribution to rural extension quality are the ability (0.81), then farmers motivation $(0.77)$, attitude $(0.74)$; knowledge $(0.71)$; and prowess $(0.67)$. Whereas soft-skill competence, which is formed from three indicators, namely problem solving, gave the biggest contribution (0.82), then persuasive skill (0.81), and systematic planning (0.73). These results show that the agricultural extension quality of the five indicators can only improve problem-solving skills, communication skills, and systematic planning abilities. The better the quality of the agricultural instructor, the better the three abilities of the mentored farmers.

The next test results are the relationship between agricultural extension quality and productivity of farmers showing the coefficient value with loading factor $=0.204$; $C . R=1,783$; and $p$-value $=0.075$ thus $\mathrm{H} 2$ is rejected. So that agricultural extension quality has a positive but insignificant effect on farmers' productivity, this result means that increasing agricultural extension quality is not significantly able to increase farmers' productivity. Three indicators measure the productivity of farmers in this study with each contribution, namely efficiency (0.84), quality (0.84), and effectiveness $(0.83)$. This result also means that the increase in ability, farmers' motivation, attitude, knowledge, and progress does not significantly affect the productivity of farmers, which is marked by improvements in efficiency, quality, and effectiveness. A good agricultural extension quality cannot directly encourage improvement in farmer productivity; it appears that there is a contribution to improvement but not significant for increasing the efficiency, effectiveness, and quality of farmer productivity measures in this study.

Other test results are the relationship between soft-skill competence against farmers' productivity, showing the coefficient value with loading factor $=0.740$; $\mathrm{C} . \mathrm{R}=5,539$ and $\mathrm{p}$-value $=0,000$; thus, $\mathrm{H} 3$ is accepted. These results indicate that soft competence has a positive and significant effect on farmers' productivity; the better the soft-skill competence will increase farmers' productivity. These results indicate an increase in problem-solving, persuasive skills, and systematic planning to increase soft-skill competence, contributing to farmers' productivity. Compared to the contribution between agricultural extension quality and soft-skill competence to the increase in farmers' productivity, the contribution of increasing problem solving, persuasive skills, and systematic planning as a measure of increasing soft-skill competence is more significant contributes significantly.

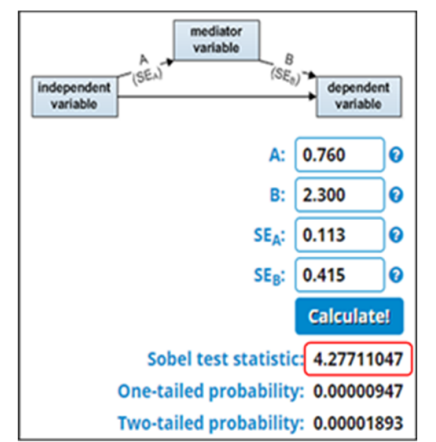

Fig. 3. Online Sobel-Test Result

The last test results with the Sobel-test (Fig. 3) as the indirect impact of agricultural extension quality on farmers' productivity through soft-skill competence shows the coefficient value with loading factor $=0.541 \mathrm{C}$. $\mathrm{R}=4.28$; thus, H4 is accepted. So that the results of this test show agricultural extension quality has a significant indirect effect on farmers' productivity. So that it describes soft-skill competence as a good mediator in this study, with the existence of soft-skill competence strengthening the contribution of agricultural extension quality to the productivity of farmers, this is because the effect of agricultural extension quality on the productivity of farmers is more significant through soft-skill competence (standardized estimates indirect effect $=0.541)$ compared with its direct result $(0.204)$. This means that in this research, agricultural extension quality can make a real contribution to farmers' productivity through soft-skill competence compared directly. 


\section{Discussion}

Characteristics of the Structural Equation Model (Table 3) to describe the quality of extension on the soft-skill competency of farmers with farmer productivity, the chi-square value $=4.277$ indicates a highly significant statistical likelihood ratio $(\mathrm{P}$ $<0.00$ ), indicating a lot of variation in farmer productivity. The standardized estimate is 0.541 , indicating that the explanatory variable explains the variation in farmer productivity. The findings in table 3 show that problem-solving, persuasive skills and systematic planning are significant determinants of farmer productivity. In contrast, the ability variables, farmers' motivation, attitude, knowledge, prowess are not significant predictors.

Respondents' soft-skill competency significantly affects productivity; farmers with a sizable soft-skill competency are more likely to implement extension recommendations, which help them improve the productivity and quality of agricultural commodities. This finding is in line with the results of Ma'sum \& Saleh (2012), Morgan et al. (2010), and Xiaogang (2016), which relate the size of soft-skill competency to farmer productivity in extension services.

Despite the importance of quality agricultural extension workers' efficient use of resources, reducing farmers' exposure to economic risks, and building more stable ecosystems over time (Lancaster \& Torres, 2019), their effect on farmer productivity is negatively significant. The probability for productivity with quality extension services is 0.20 times smaller for farmers with diversified production. These results are consistent with our results, which show that the diversity component is the lowest extension service quality attribute perceived by the respondents. In other words, focusing on providing quality extension services in one activity or soft-skill competency activity can increase farmer productivity. A possible explanation of these results is that diverse agrosystems do not characterize the study area. This result is not supported by Rehima et al. (2013), which found a positive effect of diversification of extension workers on farmer productivity with extension services provided in climate change.

Furthermore, the soft-skill competency of farmers in extension has a significant effect on farmer productivity. Productivity opportunities are found to increase by a factor of 4,27 when farmers have soft skills in extension services. Since the extension is the primary source of farmers' soft skills on agricultural innovation, their soft skill increases; although this result only implies the effectiveness of extension services, it shows that the soft skills of respondents in most extension services are high. This may be due to the effectiveness of the outreach methods used to announce the services provided. Public extension services in Indonesia mainly regulate group methods such as extension meetings to transfer extension messages. Farmers were unable to attend these meetings due to local circumstances or their lack of awareness. These results are consistent with previous studies (Baon et al., 2014; Perry et al., 2009; Raimi et al., 2017; Setiawan et al., 2021; Tauer, 2017), which confirmed the critical role of extension participation. In increasing farmer productivity.

The results for problem-solving also confirm that an increase in soft skills by 0.82 increases the possibility of productivity with the quality of extension services. As explained in this study, the impact of soft skills provides an opportunity to increase farm productivity and gain a sustainable competitive advantage. Therefore, it makes sense that the higher the quality of problem-solving acquired, the greater the likelihood of farmers' overall productivity of extension services. Our results are consistent with previous research (Bahn \& McAleer, 2007; Effendy, 2020; Kroma, 2006), which emphasized that farmer problem solving is a significant determinant of farmer productivity towards extension services.

Despite our expectations, the quality level of extension workers was not significant in terms of farmer productivity. According to Bucci et al. (2018), perceived value (increased production) and perceived quality are drivers of farmer productivity. As a result, these fundamental parameters were observed by farmers with different quality levels of extension workers, consistent with the results of previous work (Abdullah \& Samah, 2013; Agholor et al., 2013; Ahmad et al., 2007; Hauser et al., 2016; Kassem et al., 2020). However, other studies (Golob, 2009; Hauser et al., 2016; Margono \& Sugimoto, 2011) reported a significant effect of the quality of extension workers on increasing farmer productivity. However, essential limitations may affect the generalizability of the findings and can help direct future research directions. This study relied on a random sample of farmers in each area without including different stakeholders or selecting farmers from different geographic areas.

\section{Conclusion}

This study examines the quality of agricultural extension services and explores the factors that explain variations in the productivity of Indonesian farmers. Respondents indicated their productivity with the quality of services provided by the public sector in terms of the quality of agricultural extension workers and soft-skill competency of farmers. We conclude that farmers are productive with extension services through soft-skill competency owned by farmers. Farmers share the same opinion regarding this service in terms of extension quality attributes. They are satisfied with the variety of services, implying that these services need to be improved in providing services for different agricultural activities to different stakeholders using different extension methods. The results of the research model highlight aspects that public extension workers must improve to increase farmer productivity. Empirical results show that the quality of extension workers and soft-skill competence positively affect farmer productivity. Therefore, this study recommends adopting participatory methods, such as farmer soft-skill competency, to facilitate disseminating and exchanging information between farmers and extension workers. In addition, efforts should focus on persuading farmers to upgrade skills and choosing extension technologies that increase 
the economic benefits of agriculture. There is a need to provide recommendations according to the principle of demanddriven extension appropriate to the socio-economic situation in the study area and the nature of the agricultural system. Furthermore, the study recommends developing accountability mechanisms by promoting participatory monitoring and evaluation of extension services to meet farmer expectations. Future research areas should focus on methods and approaches that can improve the quality of extension services. Such studies can contribute to increasing agricultural productivity.

\section{Acknowledgement}

Thank you to the Postgraduate Program of STIE Amkop Makassar, Postgraduate School of Hasanudiin University, and STIA Puangrimaggalatung for supporting this research. Thanks also to the Agricultural Extension in South Sulawesi and West Sulawesi, especially those who have filled out the questionnaire to carry out this research.

\section{References}

Abdullah, F. A., \& Samah, B. A. (2013). Factors impinging farmers' use of agriculture technology. Asian Social Science, $9(3), 120$.

Adnan, N., Nordin, S. M., \& bin Abu Bakar, Z. (2017). Understanding and facilitating sustainable agricultural practice: A comprehensive analysis of adoption behaviour among Malaysian paddy farmers. Land Use Policy, 68, 372-382.

Agholor, I. A., Monde, N., Obi, A., \& Sunday, O. A. (2013). Quality of extension services: A case study of farmers in Amathole. Journal of Agricultural Science, 5(2), 204.

Ahmad, M., Akram, M., Rauf, R., Khan, I. A., \& Pervez, U. (2007). Interaction of extension worker with farmers and role of radio and television as sources of information in technology transfer: a case study of four villages of district Peshawar and Charsadda. Sarhad Journal of Agriculture, 23(2), 515.

Ajayi, O. C. (2007). User acceptability of sustainable soil fertility technologies: Lessons from farmers' knowledge, attitude and practice in southern Africa. Journal of Sustainable Agriculture, 30(3), 21-40.

Aker, J. C. (2011). Dial "A" for agriculture: a review of information and communication technologies for agricultural extension in developing countries. Agricultural Economics, 42(6), 631-647.

Almeqbali, S. R. M., \& Kasim, R. (2020). Structural Equation Modeling (SEM-AMOS) Analysis on Abu Dhabi MGovernment Service Quality and Customer Satisfaction. Psychology and Education Journal, 57(9), 5570-5575.

Altieri, M. A., \& Nicholls, C. I. (2017). The adaptation and mitigation potential of traditional agriculture in a changing climate. Climatic Change, 140(1), 33-45.

An Extension of Competence and Technology in Supporting the Effectiveness of Kostra Tani's Program on Agricultural Products. (2018).

Anderson, J. R., \& Feder, G. (2004). Agricultural extension: Good intentions and hard realities. The World Bank Research Observer, 19(1), 41-60.

Anderson, J. R., \& Feder, G. (2007). Agricultural extension. Handbook of Agricultural Economics, 3, $2343-2378$.

Bahn, H. M., \& McAleer, P. (2007). US Agricultural extension services: Adapting farmer education to contemporary market requirements. India-US Agricultural Knowledge Initiative, New Delhi.

Baloch, M. A., \& Thapa, G. B. (2018). The effect of agricultural extension services: Date farmers' case in Balochistan, Pakistan. Journal of the Saudi Society of Agricultural Sciences, 17(3), 282-289.

Baon, J. B., Prawoto, A. A., Wibawa, A., \& Abdoellah, S. (2014). Increasing cocoa productivity and farmer capacity in surrounding area of PT Kaltim Prima Coal and PT Berau Coal. Journal of Degraded and Mining Lands Management, 1(2), 97-104.

Baron, R. M., \& Kenny, D. A. (1986). The moderator-mediator variable distinction in social psychological research: Conceptual, strategic, and statistical considerations. Journal of Personality and Social Psychology, 51(6), 1173.

Belay, K., \& Abebaw, D. (2004). Challenges facing agricultural extension agents: A Case Study from South-western Ethiopia. African Development Review, 16(1), 139-168.

Berry, D. P., \& Cromie, A. R. (2007). Farmer satisfaction: potential for genetic evaluation in Ireland? Proceedings of the British Society of Animal Science, 2007, 51.

Besser, T., \& Mann, S. (2015). Which farm characteristics influence work satisfaction? An analysis of two agricultural systems. Agricultural Systems, 141, 107-112.

Bloemer, J., De Ruyter, K. O., \& Wetzels, M. (1999). Linking perceived service quality and service loyalty: a multidimensional perspective. European Journal of Marketing, 33(11/12), 1082-1106.

Brown, T. A., \& Moore, M. T. (2012). Confirmatory factor analysis. Handbook of Structural Equation Modeling, $361-379$.

Brunori, G., Rossi, A., \& Malandrin, V. (2011). Co-producing transition: Innovation processes in farms adhering to solidaritybased purchase groups (GAS) in Tuscany, Italy. The International Journal of Sociology of Agriculture and Food, 18(1), 28-53.

Bucci, G., Bentivoglio, D., \& Finco, A. (2018). Precision agriculture as a driver for sustainable farming systems: state of art in literature and research. Calitatea, 19(S1), 114-121.

Cai, L., \& Lee, T. (2009). Covariance structure model fit testing under missing data: An application of the supplemented EM algorithm. Multivariate Behavioral Research, 44(2), 281-304.

Chapman, R., \& Tripp, R. (2003). Changing incentives for agricultural extension: A review of privatised extension in practice.

Charatsari, C., Papadaki-Klavdianou, A., \& Michailidis, A. (2011). Farmers as consumers of agricultural education services: Willingness to pay and spend time. The Journal of Agricultural Education and Extension, 17(3), 253-266. 
Chen, W. (2020). The Institutional Innovation of the "Resource and Ecologically Sound" Transformation of Agriculture. In Challenges and Opportunities for Chinese Agriculture (pp. 419-509). Springer.

Chowa, C., Garforth, C., \& Cardey, S. (2013). Farmer experience of pluralistic agricultural extension, Malawi. The Journal of Agricultural Education and Extension, 19(2), 147-166.

Comoé, H., \& Siegrist, M. (2015). Relevant drivers of farmers' decision behavior regarding their adaptation to climate change: a case study of two regions in Côte d'Ivoire. Mitigation and Adaptation Strategies for Global Change, 20(2), 179-199.

Deichmann, U., Goyal, A., \& Mishra, D. (2016). Will digital technologies transform agriculture in developing countries? Agricultural Economics, 47(S1), 21-33.

Devi, K., \& Tripathi, R. (2020). Social Network Analysis for efficient delivery of Agricultural Extension Services. 2020 11th International Conference on Computing, Communication and Networking Technologies (ICCCNT), 1-6.

Dondero, H. E. (2019). Soft Skill Development through the Agricultural Ambassador State Conference.

Economics. (2021). Indonesia GDP From Agriculture. Trading Economics. https://tradingeconomics.com/indonesia/gdpfrom-agriculture

Effendy, L. (2020). The farmer capacity improvement model On the implementation of rice field. Journal of the Social Sciences, 48(2).

Elias, A., Nohmi, M., Yasunobu, K., \& Ishida, A. (2016). Farmers' satisfaction with agricultural extension service and its influencing factors: a case study in North West Ethiopia. Journal of Agricultural Science and Technology, 18(1), 39-53.

Etikan, I., Musa, S. A., \& Alkassim, R. S. (2016). Comparison of convenience sampling and purposive sampling. American Journal of Theoretical and Applied Statistics, 5(1), 1-4.

Eze, C. C., Lemchi, J. I., Ugochukwu, A. I., Eze, V. C., Awulonu, C. A. O., \& Okon, A. X. (2010). Agricultural financing policies and rural development in Nigeria.

Feder, G., Birner, R., \& Anderson, J. R. (2011). The private sector's role in agricultural extension systems: potential and limitations. Journal of Agribusiness in Developing and Emerging Economies, 1(1), 31-54.

Feder, G., Willett, A., \& Zijp, W. (2001). Agricultural extension: Generic challenges and the ingredients for solutions. In Knowledge generation and technical change (pp. 313-353). Springer.

Free, D. (2017). Perceptions of soft skill development in secondary agricultural education programs by agricultural teachers.

Freeman, S. M. (2017). An investigation of soft skill development of California Agricultural Education students participating in an FFA career development event.

Gandhi, R., Veeraraghavan, R., Toyama, K., \& Ramprasad, V. (2007). Digital green: Participatory video for agricultural extension. 2007 International Conference on Information and Communication Technologies and Development, 1-10.

Ghimire, R. P., \& Suvedi, M. (2017). A qualitative study examining core competency needs of agricultural extension professionals in Nepal. Asian Journal of Agricultural Extension, Economics \& Sociology, 1-12.

Golob, P. (2009). On-farm post-harvest management of food grains: a manual for extension workers with special reference to Africa. Agricultural and Food Engineering Training and Resource Materials, 2.

Harrington, D. (2009). Confirmatory factor analysis. Oxford university press.

Harry, M. P. (2012). Effectiveness of farmer groups as tools of extension service delivery: The case of MakhuduthamagaSekhukhune (Limpopo Province). [Bloemfontein?]: Central University of Technology, Free State.

Hauser, M., Lindtner, M., Prehsler, S., \& Probst, L. (2016). Farmer participatory research: Why extension workers should understand and facilitate farmers' role transitions. Journal of Rural Studies, 47, 52-61.

Hazell, P. B. R. (2005). Is there a future for small farms? Agricultural Economics, 32, 93-101.

Hernández-Espallardo, M., Arcas-Lario, N., \& Marcos-Matás, G. (2013). Farmers' satisfaction and intention to continue membership in agricultural marketing co-operatives: neoclassical versus transaction cost considerations. European Review of Agricultural Economics, 40(2), 239-260.

Hoang, L. A., Castella, J.-C., \& Novosad, P. (2006). Social networks and information access: Implications for agricultural extension in a rice farming community in northern Vietnam. Agriculture and Human Values, 23(4), 513-527.

Kassem, H. S., Shabana, R. M., Ghoneim, Y. A., \& Alotaibi, B. M. (2020). Farmers' perception of the quality of mobilebased extension services in Egypt: A comparison between public and private provision. Information Development, 36(2), $161-180$.

Knickel, K., Brunori, G., Rand, S., \& Proost, J. (2009). Towards a better conceptual framework for innovation processes in agriculture and rural development: from linear models to systemic approaches. Journal of Agricultural Education and Extension, 15(2), 131-146.

Knight, J., Weir, S., \& Woldehanna, T. (2003). The role of education in facilitating risk-taking and innovation in agriculture. The Journal of Development Studies, 39(6), 1-22.

Kroma, M. M. (2006). Organic farmer networks: facilitating learning and innovation for sustainable agriculture. Journal of Sustainable Agriculture, 28(4), 5-28.

Lee, D. R., Barrett, C. B., \& McPeak, J. G. (2006). Policy, technology, and management strategies for achieving sustainable agricultural intensification. Agricultural Economics, 34(2), 123-127.

Leta, G., Kelboro, G., Stellmacher, T., \& Hornidge, A.-K. (2017). The agricultural extension system in Ethiopia: operational setup, challenges and opportunities. ZEF working paper series.

Lukuyu, B., Place, F., Franzel, S., \& Kiptot, E. (2012). Disseminating improved practices: are volunteer farmer trainers effective? The Journal of Agricultural Education and Extension, 18(5), 525-540. 
Lulfs-Baden, F., Spiller, A., Zuhlsdorf, A., \& Mellin, M. (2008). Customer satisfaction in farmer-to-consumer direct marketing. International Food and Agribusiness Management Review, 11(1030-2016-82712), 49-72.

Ma'sum, M., \& Saleh, A. (2012). The Perception of Beef Cattle's Farmers on Implementation of Artificial Insemination in Three Central Areas of Beef Cattle in Indonesia. International Seminar on Animal Industry.

Mamai, O. V, Mamai, I. N., \& Kitaeva, M. V. (2019). Digitization of the agricultural sector of economy as an element of innovative development in Russia. International Scientific Conference "Digital Transformation of the Economy: Challenges, Trends, New Opportunities, "359-365.

Margono, T., \& Sugimoto, S. (2011). The barriers of the Indonesian extension workers in disseminate agricultural information to farmers. International Journal of Basic and Applied Sciences, 11(2), 4747-7302.

Mariyono, J. (2019). Microcredit and technology adoption: Sustained pathways to improve farmers' prosperity in Indonesia. Agricultural Finance Review, 79(1), 85-106.

McCloskey, D. N., \& Ziliak, S. T. (1996). The standard error of regressions. Journal of Economic Literature, 34(1), $97-114$.

McCown, R. L. (2002). Changing systems for supporting farmers' decisions: problems, paradigms, and prospects. Agricultural Systems, 74(1), 179-220.

Meena, M., Singh, K. M., \& Swanson, B. (2015). Indian Agricultural Extension Systems and Lessons Learnt: A Review. Journal of AgriSearch, 2(4), 281-285.

Mislia, M., Alim, A., Usuf, E., Tamsah, H., \& Yusriadi, Y. (2021). The effect of training and education and teacher certification allowances on teachers. Cypriot Journal of Educational Sciences, 16(4), 1368-1383.

Morgan, S. L., Marsden, T., Miele, M., \& Morley, A. (2010). Agricultural multifunctionality and farmers' entrepreneurial skills: A study of Tuscan and Welsh farmers. Journal of Rural Studies, 26(2), 116-129.

Muwonge, A. (2007). Local government financing and provision in an institutionally constrained decentralized system: The case of agricultural extension in Uganda.

Perry, C., Steduto, P., Allen, R. G., \& Burt, C. M. (2009). Increasing productivity in irrigated agriculture: Agronomic constraints and hydrological realities. Agricultural Water Management, 96(11), 1517-1524.

Plà, L. M., Sandars, D. L., \& Higgins, A. J. (2014). A perspective on operational research prospects for agriculture. Journal of the Operational Research Society, 65(7), 1078-1089.

Poulton, C., Dorward, A., \& Kydd, J. (2010). The future of small farms: New directions for services, institutions, and intermediation. World Development, 38(10), 1413-1428.

Purnomo, S., \& Lee, Y.-H. (2010). An assessment of readiness and barriers towards ICT program implementation: Perceptions of agricultural extension officers in Indonesia. International Journal of Education and Development Using ICT, 6(3), 19-36.

Ragasa, C., Ulimwengu, J., Randriamamonjy, J., \& Badibanga, T. (2016). Factors affecting performance of agricultural extension: evidence from Democratic Republic of Congo. The Journal of Agricultural Education and Extension, 22(2), 113-143.

Rahayu, S., Laraswati, D., Pratama, A. A., Sahide, M. A. K., Permadi, D. B., Wibowo, W., Widyaningsih, T. S., Suprapto, E., Andayani, W., \& Maryudi, A. (2020). Bureaucratizing non-government organizations as governmental forest extension services in social forestry policy in Indonesia. Forests, Trees and Livelihoods, 29(2), 119-129.

Raimi, A., Adeleke, R., \& Roopnarain, A. (2017). Soil fertility challenges and Biofertiliser as a viable alternative for increasing smallholder farmer crop productivity in sub-Saharan Africa. Cogent Food \& Agriculture, 3(1), 1400933.

Rehima, M., Belay, K., Dawit, A., \& Rashid, S. (2013). Factors affecting farmers' crops diversification: Evidence from SNNPR, Ethiopia. International Journal of Agricultural Sciences, 3(6), 558-565.

Rivera, W. M. (2011). Public sector agricultural extension system reform and the challenges ahead. Journal of Agricultural Education and Extension, 17(2), 165-180.

Riyanti, B. P. D., Sandroto, C. W., \& DW, M. T. W. (2017). Soft Skill Competencies, Hard Skill Competencies, and Intention to Become Enterpreneur of Vocational Graduates. International Research Journal of Business Studies, 9(2).

Robertson, G. P., \& Swinton, S. M. (2005). Reconciling agricultural productivity and environmental integrity: a grand challenge for agriculture. Frontiers in Ecology and the Environment, 3(1), 38-46.

Rota, C., Pugliese, P., Elnady, M., \& Zanasi, C. (2021). Measuring Egyptian Farmers' Attitude towards Staying Organic. Sustainability, 13(14), 7978.

Rusliyadi, M., Jamil, A., Othman, M., \& Kumalasari, R. T. (2018). Agricultural extension policy, agricultural growth and poverty reduction in Indonesia. International Journal of Engineering \& Technology, 7(4), 5539-5550.

Setiawan, I. P., Fachmi, M., Fattah, M. N., Rasyid, I., \& Yusriadi, Y. (2021). Teamwork is an Intervening Variable, The Quality of Agricultural Extension Agents on Farmer Productivity, from A Human Capital Perspective. Review of International Geographical Education Online, 11(4), 1389-1397.

Shamsudin, H. (2020). Mediating role of organizational innovation on market orientation and business performance: SEMAMOS approach.

Simpson, A. P., \& Calitz, A. P. (2015). Adapted SERVQUAL for evaluating the provision of information as an agricultural extension service in South Africa. South African Journal of Agricultural Extension, 43(2), 66-77.

Statistik. (2020). Kesejahteraan Petani Indonesia Membaik. Kementerian Pertanian. https://www.pertanian.go.id/home/?show=news\&act=view\&id=3246

Sveiby, K.-E., \& Lloyd, T. (2010). Methods for measuring intangible assets. 
Swanson, B. E. (2006). Extension strategies for poverty alleviation: lessons from China and India. Journal of Agricultural Education and Extension, 12(4), 285-299.

Tauer, L. W. (2017). Farmer productivity by age over eight US census years. International Farm Management Association Conference, 2-7.

Voicu, R., \& Radulescu, C. V. (2015). Improving agricultural productivity and possible implications in the relations of this branch with the natural environment. Calitatea, 16(S1), 17.

Wan Omar, W. A., \& Hussin, F. (2013). Transformational leadership style and job satisfaction relationship: A study of structural equation modeling (SEM). International Journal of Academic Research in Business and Social Sciences (IJARBSS), 3(2), 346-365.

Weber, M. R., Finley, D. A., Crawford, A., \& Rivera Jr, D. (2009). An exploratory study identifying soft skill competencies in entry-level managers. Tourism and Hospitality Research, 9(4), 353-361.

Widayati, T. (2019). Between environmental performance and agricultural productivity: assessing the convergence and divergence of demand-driven agricultural extension. 670216917.

Xiaogang, W. (2016). Correlation between Employment Quality and Skill Training of Land-expropriated Farmers. Asian Agricultural Research, 9.

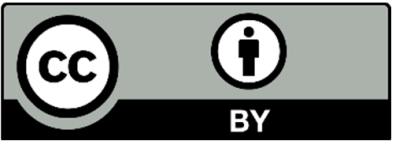

(C) 2022 by the authors; licensee Growing Science, Canada. This is an open access article distributed under the terms and conditions of the Creative Commons Attribution (CCBY) license (http://creativecommons.org/licenses/by/4.0/). 